\title{
Effects of tropospheric ozone on white clover plants exposed in open-top chambers or protected by the antioxidant ethylene-diurea (EDU)
}

\author{
I Fumagalli $^{1 *}, \mathrm{~L}$ Mignanego ${ }^{2}, \mathrm{G}_{\text {Violini }}{ }^{3}$ \\ $I^{*}$ ENEL Spa, CRAM, Environmental and Materials Research Centre, Via Rubattino 54, I-20134 Milano; \\ ${ }^{2}$ Phytos Snc, Via Madonna delle Nevi 11, I-20046, Biassono (MI); \\ ${ }^{3}$ Istituto Patologia Vegetale, Università di Milano, Via Celoria 2, I-20133, Milano, Italy
}

(Received 2 December 1996; accepted Ist June 1997)

\begin{abstract}
Summary - Tropospheric ozone concentration in a large part of Europe is high enough to cause visible injury to sensitive plants and several crop species. In this paper the results are reported of a research carried out within UNECE ICP-Crops co-ordination in 1994. Effects of tropospheric ozone on vegetation in the Milan (Italy) experimental site are evaluated using white clover plants. Plants were exposed to the air and sprayed with water or ethylene-diurea (EDU) as antioxidant. Another set of plants were exposed in open-top chambers in filtered or unfiltered air. The data suggest that summertime ozone concentrations can be sufficient to produce visible leaf injury to white clover plants of a sensitive cultivar. Moreover, data show a slight reduction in dry weight owing to ozone exposure; the loss is about $10 \%$ for water-treated plants versus EDU-treated plants and $19.8 \%$ for exposure to unfiltered air compared with filtered air at the final harvest.
\end{abstract}

ozone / Trifolium repens / leaf injury / open-top chamber / ethylene-diurea

Résumé - Effets de l'ozone troposphérique sur des plantes de trèfle blanc cultivées dans des chambres à toit ouvert ou traitées avec l'antioxydant éthylène-diurée (EDU). La concentration d'ozone au niveau de la troposphère est suffisamment élevée dans une grande partie de l'Europe pour causer des dommages visibles aux plantes sensibles et à de nombreuses espèces cultivées. Cet article illustre les résultats d'une recherche effectuée en 1994 dans le cadre du Programme international de coopération sur les effets des polluants atmosphériques sur les cultures (UNECE ICP-Crops). Les plantes ont été exposées en plein air et arrosées avec de l'eau ou de l'éthylène-diurée (EDU) comme antioxidant. Une partie des plantes a été placée dans des chambres à toit ouvert avec air filtré ou non-filtré. Les données montrent que les concentrations estivales d'ozone sont en mesure de produire des dommages visibles aux feuilles d'un cultivar sensible de trèfle blanc. Les données montrent aussi une faible perte de production en poids sec due à l'exposition à l'ozone; cette perte se situait à $-10 \%$ pour les plantes traitées avec de l'eau par rapport aux plantes traitées avec l'EDU et à $-19,8 \%$ pour la récolte finale des plantes exposées à l'air non-filtré, par rapport à celles exposées à l'air filtré.

ozone / Trifolium repens / dommage foliaire / chambre à ciel ouverte / éthylène-diurée

Article communicated by Marco Trevisan (Piacenza)

* Correspondence and reprints

Tél : (39) 2 72243921; fax : (39) 2 72243915; e-mail: fumagalli@ cram.enel.it 


\section{INTRODUCTION}

Ambient ozone, the major component of photochemical oxidants, may reach phytotoxic levels for many agricultural crops, and the deleterious effects of high concentrations of ozone on crop yield are well assessed (Heagle, 1989). Furthermore tropospheric ozone concentrations in a large part of Europe are high enough to cause visible injury to sensitive plants, such as tobacco $\mathrm{cv}$ Bel W3, white clover (Trifolium repens) and red clover (Trifolium pratense) cultivars, bean and soybean plants and other species (Pleijel et al, 1994; Sanders and Benton, 1995).

Several methods and different experimental approaches to assess the effects of ambient ozone on plants are used (Schenone and Lorenzini, 1992); among these, atmospheric pollutant exclusion by air filtration and antioxidant treatments on plants. Air filtration tests are usually conducted in open-top chambers (OTCs) or in greenhouses with air-forced ventilation. The antioxidant ethylene-diurea (EDU) is probably the main protective substance used in experiments on the effects of ambient ozone on vegetables and it is considered to be a useful tool for studying the basis of ozone tolerance in plants (Heagle, 1989; Ainsworth et al, 1996). EDU treatments can delay and attenuate the harmful effects of ozone, such as premature senescence and/or visible injury on leaves.

Ozone concentrations in Italy are often very high in the summer and since 1986 the Italian electricity utility (ENEL spa) has been developing a research programme in the Po valley using filtration experiments with open-top chambers (OTCs) and EDU treatments to verify the effects of air pollution, ozone in particular, on agricultural crops (Schenone et al, 1992). The programme has been carried out as part of the International Cooperative Programme on the effects of air pollutants on crops (ICP-Crops) promoted by the UN-ECE Convention on Long-Range Transboundary Air Pollution. The aim of these experiments was to assess the effects of ambient ozone on plants by short-term (visible injury) and longterm responses (yield loss).

The results of the 1994 experiments carried out at the Milan experimental site using clover plants are presented here.

\section{MATERIALS AND METHODS}

The experiments were performed at a field site in Redecesio di Segrate (Milan) from 17 May to

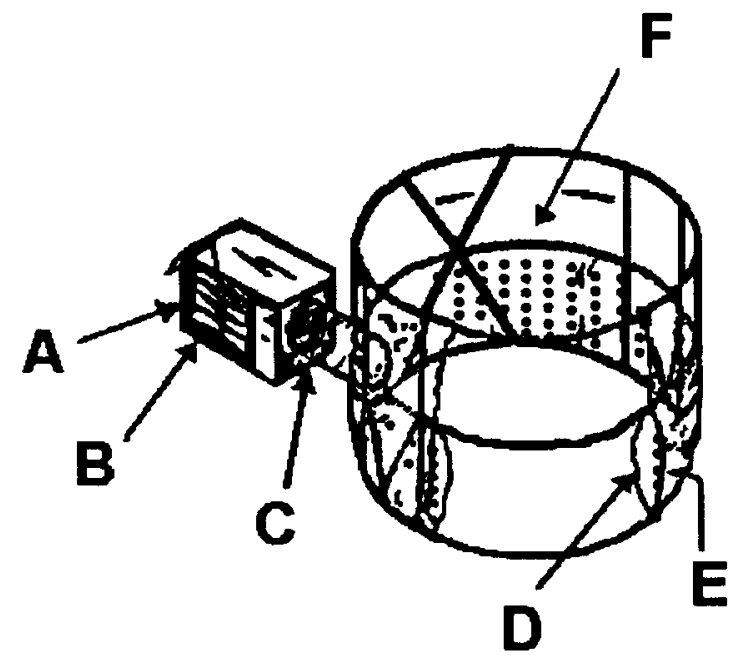

Fig 1. Open-top field chamber from Heagle et al (1973). (A) Particulate filter; (B) purafill and activated charcoal filters; (C) fan; (D) internal perforated PVC sheet; (E) external PVC sheet; (F) upper PVC sheet.

20 September 1994. At the experimental site both open-top chambers (OTCs) and an unenclosed field plot were available. An automatic air pollution monitoring system was used inside and outside the OTCs.

\section{Open-top chambers}

Eight open-top chambers were used, four of which were equipped with charcoal/purafill filters to remove air pollutants (filtered air), and four with empty filters (unfiltered air). The OTCs were similar to those described by Heagle et al (1973) but modified to reduce their size $(2 \mathrm{~m}$ in diameter and $1.60 \mathrm{~m}$ high, $\left.5 \mathrm{~m}^{3} \mathrm{vol}\right)$ in order to optimise the volume to growing surface rate ratio (fig 1). Air speed through all the filters was measured weekly with a portable anemometer and air flow was kept constant for all chambers. The ventilation rate was about $750 \mathrm{~m}^{3} \mathrm{~h}^{-1}$, with 2.5 air changes $\mathrm{min}^{-1}$. The treatment consisted in exposing the plants to ambient unfiltered air (NF); the control was provided by plants grown in chambers ventilated with filtered air $(\mathrm{F})$.

\section{Air pollutants monitoring}

The monitoring of air quality was performed with automatic analysers for sulphur dioxide (Monitor Labs, fluorescence detector, detection limit $1 \mathrm{ppb}$, precision $2 \mathrm{ppb}$ ); nitrogen oxides (Monitor Labs, chemioluminescence system, detection limit $1 \mathrm{ppb}$, precision $2 \mathrm{ppb}$ ) and ozone (Monitor Labs, UV absorption, detection limit $1 \mathrm{ppb}$, precision $2 \mathrm{ppb}$ ). Ambient air samplers (AA) were placed at about $2.5 \mathrm{~m}$ above the soil surface. Inside the chambers, both filtered $(\mathrm{F})$ and 
unfiltered (NF) air samples were taken at about $1 \mathrm{~m}$ above the ground. Every line (AA, F, NF) had a sampling time of $10 \mathrm{~min}$, performed twice every hour for $23 \mathrm{~h}$ each day. Each analyser was automatically calibrated at $12 \mathrm{pm}$ daily. The raw data were stored on a data logger and processed on a PC and a mainframe computer (VAX 8530).

Ozone exposure levels have been summarised into 24-h and 7-h means (1000-1700 hours GMT), mean daily maximum, maximum hourly mean and cumulative dose over a threshold of $40 \mathrm{ppb}$. The ozone dose (AOT40) was calculated as the sum of the difference between the hourly concentration and $40 \mathrm{ppb}$ for each hour during which the concentration exceeds $40 \mathrm{ppb}$, according to UN-ECE (1994a) experimental protocol. The AOT40 is accumulated for daylight hours only when global solar radiation exceeds $50 \mathrm{Wm}^{-2}$. Probes for air temperature and humidity were installed above the plant canopy both in the external plot and inside the chambers (F and NF).

For a more detailed description of the OTCs and the air pollutant monitoring system see Schenone et al (1989).

\section{Cultural condition}

White clover plants (Trifolium repens cv Menna) were grown in $10 \times 10$-cm self-watering pots in a mixture of soil and peat (1:1) fertilised with $2.5 \mathrm{~g}$ of $8-24-24$ $(\mathrm{N}-\mathrm{P}-\mathrm{K})$ per pot. The plants were sown in a greenhouse with nine seeds per pot. When the first spade leaf emerged, plants were thinned leaving three evenly spaced, healthy and evenly growing plants in each pot, according to UN-ECE protocol (UN-ECE, 1994a). Eighty pots were then transferred to the experimental site, and the date of emergence of the first trifoliate leaf was recorded as 'DAY 0'. The subsequent days were indicated as 'days after emergence of the first trifoliate leaf' (DAET).

Five pots were maintained in each OTC for the whole experiment. Forty pots were kept in an unenclosed field plot and treated with EDU or water, as reported in the following.

All pots were manually irrigated at least twice a week in addition to rainfall. Once a week an insecticide (Phosalone 24\%) was sprayed onto the plants as a preventive measure.

\section{Plant treatments}

Every 2 weeks starting from the emergence of the first trifoliate leaf (DAY 0), 20 pots in the unenclosed field plot were sprayed with $N$-[2-(oxo-1-imidazolidinyl) ethyl]- $N$ '-phenylurea (ethylene diurea, abbreviated EDU), as a soil drench, using $100 \mathrm{~mL}$ of a $150 \mathrm{ppm}$ solution (+EDU pots). Four applications were performed for each field experiment, administering a total of $60 \mathrm{mg}$ of EDU per pot. Another set of 20 pots were sprayed with tap water (-EDU pots). The +EDU and -EDU treatment pots were randomly arranged in four rows of ten pots; spacing between rows was $1 \mathrm{~m}$ and the distance between pots was $0.25 \mathrm{~m}$.

No EDU was supplied to pots inside the OTCs, where the treatments were unfiltered ambient air (NF) and filtered ambient air (F), as described earlier.

To make the text drafting easy, +EDU and F plants are labelled 'protected' plants (from ozone) and-EDU and NF plants are labelled 'unprotected' plants.

\section{Harvest procedure and statistical analyses}

For the whole experimental season, all pots were checked twice a week to record the date on which visible symptoms of ozone damage appeared. These symptoms will be described in the results section.

On 28 DAET the first harvest was performed by cutting any fully expanded trifoliate leaves from the main shoot and side shoots above the growing point. Plants were then left for a further 28 days to allow regrowth. On 56 DAET the final harvest was carried out. The growth period (GP) from DAY 0 to the first harvest and from the first harvest to the final harvest are labelled GPI and GPII, respectively.

At both harvests the number of healthy (green), senescent (yellow) and ozone-injured leaves for each pot was counted. Then cut biomass for each pot was dried and the dry weight was determined.

The total number of leaves, the percentage of leaves in each category (healthy, senescent, ozone-injured) and the dry weight were used to calculate treatment means. The homogeneity of variance was tested with different tests (Bartlett, Cochran and Hartley's test). Differences between treatments using all parameters were analysed for each harvest using one-way

Table I . Schedule of the 1994 experiments with clover plants.

\begin{tabular}{|c|c|c|c|c|c|}
\hline & Sowing date & $D A Y O$ & First harvest & Final harvest & Treatments ${ }^{a}$ \\
\hline & \multicolumn{5}{|c|}{$<=G P I=><P I I \Longrightarrow$} \\
\hline Experiment 1 (in field) & 17 May & 7 June & 5 July & 2 August & +EDU/-EDU \\
\hline Experiment 2 (in field) & 27 June & 20 July & 22 August & 20 September & $+\mathrm{EDU} /-\mathrm{EDU}$ \\
\hline Experiment 3 (inside OTCs) & 27 June & 20 July & 22 August & 20 September & $\mathrm{F} / \mathrm{NF}$ \\
\hline
\end{tabular}

a +EDU: pots sprayed with EDU; -EDU: pots sprayed with water; F: pots exposed to filtered air; NF: pots exposed to unfiltered air. 
Table II. Climate data assessed in ambient air over different growth periods during 1994 clover trials.

\begin{tabular}{|c|c|c|c|c|c|c|c|c|c|}
\hline \multirow[b]{2}{*}{ Growth period $(G P)$} & \multicolumn{3}{|c|}{$\begin{array}{c}\text { Air temperature } \\
\left({ }^{\circ} \mathrm{C}\right)\end{array}$} & \multicolumn{3}{|c|}{$\begin{array}{c}\text { Air humidity } \\
(\%)\end{array}$} & \multirow{2}{*}{ 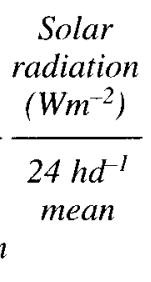 } & \multicolumn{2}{|c|}{ Rainfall ${ }^{b}$} \\
\hline & $\begin{array}{c}24 \text { hd }^{1} \\
\text { mean }\end{array}$ & $\begin{array}{c}\text { Mean } \\
\text { daily } \\
\text { minimum }\end{array}$ & $\begin{array}{c}\text { Mean } \\
\text { daily } \\
\text { maximum }\end{array}$ & $\begin{array}{c}24 \mathrm{hd}^{-1} \\
\text { mean }\end{array}$ & $\begin{array}{c}\text { Mean } \\
\text { daily } \\
\text { minimum }\end{array}$ & $\begin{array}{c}\text { Mean } \\
\text { daily } \\
\text { maximum }\end{array}$ & & $\begin{array}{c}\text { Number } \\
\text { of } \\
\text { days }\end{array}$ & $m m$ \\
\hline \multicolumn{10}{|l|}{ Experiment 1} \\
\hline Emergence $^{a}$ to 1 st harvest (GPI) & 21.6 & 11.7 & 20.0 & 64 & 29 & 70 & 222 & 7 & 87.4 \\
\hline 1st harvest to final harvest (GPII) & 24.4 & 17.1 & 30.5 & 62 & 32 & 96 & 235 & 5 & 60.6 \\
\hline Emergence $^{a}$ to final harvest & 23.3 & 14.4 & 25.2 & 63 & 30 & 83 & 228 & 12 & 148.0 \\
\hline \multicolumn{10}{|l|}{ Experiment 2 and Experiment 3} \\
\hline Emergence ${ }^{a}$ to 1 st harvest (GPI) & 24.4 & 16.7 & 31.3 & 63 & 28 & 98 & 223 & 4 & 44.2 \\
\hline 1st harvest to final harvest (GPII) & 19.8 & 13.5 & 26.3 & 72 & 39 & 98 & 157 & 12 & 283.2 \\
\hline Emergence $^{a}$ to final harvest & 22.3 & 15.2 & 29.0 & 67 & 33 & 98 & 192 & 16 & 327.4 \\
\hline
\end{tabular}

${ }^{a}$ Emergence of first trifoliate leaf (DAY 0); ' data from 'Milano 2' Ersal Station (500 m distance).

ANOVA. If necessary data expressed as percentages were previously transformed into the arcsine of the square root of the original values.

Three experiments were performed with the experimental schedule shown in table I.

\section{RESULTS}

\section{Air quality}

Climate data assessed in ambient air over different growth periods are reported in table II. Inside the chambers the temperature was about $1{ }^{\circ} \mathrm{C}$ higher than in the field plots, with no difference between the NF and F OTCs. The relative humidity was similar inside and outside the open-top chambers.

Ambient air pollutants monitored during the trial from June to September were $\mathrm{SO}_{2}, \mathrm{NO}, \mathrm{NO}_{2}$ and $\mathrm{O}_{3}$ (table III). The $\mathrm{SO}_{2}, \mathrm{NO}$ and $\mathrm{NO}_{2} 24-\mathrm{h}$ mean concentrations over the whole experimental season were, respectively, 4,14 and $19 \mathrm{ppb}$.

The average concentrations (24-h mean, 7-h mean, mean daily maximum and maximum hourly mean) of ozone during the growth periods of field experiments are shown in table IV.

In ambient air, data monitored were almost $100 \%$ of total data while, because of a few interruptions in air monitoring, inside the OTCs $25 \%$ of data were missing. These missing data have been deduced on the basis of air filtration efficiency measured on available data.

As reported in table IV for field experiments, mean calculated $\mathrm{O}_{3}$ levels from day 0 to the final harvest were higher in experiment 1 than in experiment 2 , although the differences between mean concentrations were less than $10 \mathrm{ppb}$. Referring to the growth periods, $\mathrm{O}_{3}$ parameters for the GPI of experiment 2 were quite similar to both growth periods of experiment 1. During these growth periods the clover plants were exposed to the highest value of ozone, corre-

Table III. Air quality at field site for experimental season in 1994 (24-h mean - ppb).

\begin{tabular}{llccccc}
\hline \multirow{5}{*}{ June } & & $\mathrm{SO}_{2}$ & $\mathrm{NO}$ & $\mathrm{NOx}$ & $\mathrm{NO}_{2}$ & $\mathrm{O}_{3}$ \\
\hline \multirow{5}{*}{ July } & $\mathrm{E}$ & 2 & 9 & 28 & 19 & 40 \\
& $\mathrm{NF}$ & 1 & 5 & 21 & 16 & 35 \\
& $\mathrm{~F}$ & $<1$ & 4 & 17 & 13 & 16 \\
& $\mathrm{E}$ & 3 & 7 & 25 & 18 & 45 \\
August & $\mathrm{NF}$ & 2 & 6 & 21 & 15 & 40 \\
& $\mathrm{~F}$ & $<1$ & 5 & 18 & 13 & 18 \\
& $\mathrm{E}$ & 5 & 8 & 22 & 14 & 40 \\
\multirow{5}{*}{ September } & $\mathrm{NF}$ & 4 & 7 & 18 & 11 & 36 \\
& $\mathrm{~F}$ & $<1$ & 5 & 15 & 10 & 16 \\
& $\mathrm{E}$ & 5 & 30 & 56 & 26 & 20 \\
& $\mathrm{NF}$ & 4 & 25 & 48 & 23 & 18 \\
& $\mathrm{~F}$ & $<1$ & 22 & 44 & 22 & 8 \\
\hline
\end{tabular}

E: External plot; NF: unfiltered open-top chambers; F: filtered open-top chambers 
Table IV. Ozone exposure parameters assessed for different growth periods during 1994 clover trials.

\begin{tabular}{|c|c|c|c|c|c|}
\hline \multirow[b]{2}{*}{ Growth period (GP) } & \multicolumn{4}{|c|}{ Concentration (ppb) } & \multirow[b]{2}{*}{$\begin{array}{l}A O T 40 \\
(p p b h)\end{array}$} \\
\hline & $24 \mathrm{hd}^{-1}$ mean & $\begin{array}{l}7 \mathrm{hd}^{-1} \text { mean } \\
(10-17 \mathrm{~h})\end{array}$ & $\begin{array}{l}\text { Mean daily } \\
\text { maximum }\end{array}$ & $\begin{array}{l}\text { Hourly } \\
\text { maximum }\end{array}$ & \\
\hline \multicolumn{6}{|l|}{$\begin{array}{l}\text { Experiment } 1 \\
\text { (ambient air) }\end{array}$} \\
\hline Emergence $^{\mathrm{a}}$ to 1 st harvest (GPI) & 41 & 66 & 81 & 116 & 7694 \\
\hline 1st harvest to final harvest (GPII) & 44 & 72 & 86 & 128 & 7769 \\
\hline Emergence $^{a}$ to final harvest & 43 & 69 & 84 & 128 & 15463 \\
\hline \multicolumn{6}{|l|}{$\begin{array}{l}\text { Experiment } 2 \\
\text { (ambient air) }\end{array}$} \\
\hline Emergence $^{\mathrm{a}}$ to 1 st harvest (GPI) & 41 & 71 & 87 & 134 & 8976 \\
\hline Ist harvest to final harvest (GPII) & 28 & 47 & 64 & 99 & 3122 \\
\hline Emergence $^{\mathrm{a}}$ to final harvest & 35 & 60 & 77 & 134 & 12098 \\
\hline \multicolumn{6}{|l|}{$\begin{array}{l}\text { Experiment } 3 \\
\text { (unfiltered air) }\end{array}$} \\
\hline Emergence $^{\mathrm{a}}$ to 1 st harvest $(\mathrm{GPI})$ & 37 & 63 & 78 & 119 & 6668 \\
\hline 1st harvest to final harvest (GPII) & 25 & 42 & 57 & 88 & 2188 \\
\hline Emergence $^{a}$ to final harvest & 31 & 53 & 68 & 119 & 8856 \\
\hline \multicolumn{6}{|l|}{ (Filtered air) } \\
\hline Emergence $^{a}$ to 1 st harvest (GPI) & 16 & 28 & 35 & 54 & 138 \\
\hline lst harvest to final harvest (GPII) & 11 & 19 & 26 & 40 & 0 \\
\hline Emergence $^{a}$ to final harvest & 14 & 24 & 31 & 54 & 138 \\
\hline
\end{tabular}

a Emergence of first trifoliate leaf (day 0).

sponding to the highest values of temperature and solar radiation occurring in summer months. In fact $53 \mathrm{~h}$ over $100 \mathrm{ppb}$ were recorded from June to August. At the end of August and in September mean ozone concentrations were lower. In table IV the AOT40 calculated for the same growth periods have been reported. The AOT40 from day 0 to the final harvest were 15463 $\mathrm{ppb} h$ for experiment 1 and $12098 \mathrm{ppb} \mathrm{h}$ for experiment 2 . Concerning experiment 3 , although it was performed at the same time as experiment 2 , the ozone parameters are modified by the OTC effects. For instance the $24 \mathrm{hd}^{-1}$ mean was $35 \mathrm{ppb}$ in ambient air, $31 \mathrm{ppb}$ in unfiltered air and 14 in filtered air.

\section{Macroscopic symptoms of ozone injury}

Visible symptoms on trifoliate leaves of clover plants exposed to ambient ozone were numerous small discoloured spots or stippling and yellow necrotic spots ('flecking'). Generally symptoms were distributed over the upper leaf surface of all three leaflets of one trifoliate leaf. Similar leaf symptoms have been described in clover plants exposed to ozone (Hill et al, 1970; Becker et al, 1989; Sanders and Benton, 1995). Both in plants kept inside the chambers with filtered air $(F)$ and in those grown in field plots with EDU administration these symptoms were usually not present.

Ozone was the only air pollutant reaching phytotoxic levels during the experiment (table III) and can be considered as the cause for the above symptoms.

For experiment 1 the ozone symptoms on trifoliate leaves started to be clearly visible on -EDU plants on 16 DAET (23 June), when the AOT40 was $3647 \mathrm{ppb}$. The same leaf injuries were present also on re-growing leaves after the harvest, but the date of appearance has not been precisely recorded.

For experiments 2 and 3, ozone injury symptoms appeared on unprotected plants on 12 DAET (1 August), when the AOT40 in ambient air was $3561 \mathrm{ppb}$.

After the first harvest of experiments 2 and 3, symptoms were visible again on 42 DAET (31 August), when the AOT40 calculated from the first harvest to the appearance of injury was $1214 \mathrm{ppb}$. 
Table V. Mean and standard deviation (in brackets) of the total number of leaves and dry weight per pot at first and final harvests for clover plants. For each harvest different letters indicate significant differences between means after one-way analysis of variance $(P<0.05)$.

\begin{tabular}{|c|c|c|c|c|}
\hline & \multicolumn{2}{|c|}{ First harvest } & \multicolumn{2}{|c|}{ Final harvest } \\
\hline & Unprotected $^{\mathrm{a}}$ plants & Protected $^{\mathrm{b}}$ plants & Unprotected ${ }^{\mathrm{a}}$ plants & Protected $^{\mathrm{b}}$ plants \\
\hline \multicolumn{5}{|c|}{ Experiment I (field) } \\
\hline No of leaves & $71.8(15.2)^{\mathrm{a}}$ & $72.6(18.1)^{\mathrm{a}}$ & $107.2(21.5)^{\mathrm{a}}$ & $118.6(19.0)^{\mathrm{a}}$ \\
\hline Dry weight (g) & $0.95(0.27)^{\mathrm{a}}$ & $1.05(0.30)^{\mathrm{a}}$ & $2.15(0.49)^{\mathrm{a}}$ & $2.47(0.57)^{\mathrm{a}}$ \\
\hline \multicolumn{5}{|c|}{ Experiment 2 (field) } \\
\hline No of leaves & $67.0(20.9)^{\mathrm{a}}$ & $79.1(14.9)^{\mathrm{b}}$ & $119.9(58.9)^{\mathrm{a}}$ & $136.2(51.3)^{\mathrm{a}}$ \\
\hline Dry weight $(\mathrm{g})$ & $1.02(0.35)^{\mathrm{a}}$ & $1.12(0.30)^{\mathrm{a}}$ & $2.69(1.50)^{\mathrm{a}}$ & $2.76(1.10)^{\mathrm{a}}$ \\
\hline \multicolumn{5}{|c|}{ Experiment 3 (OTC) } \\
\hline No of leaves & $65.8(16.7)^{\mathfrak{a}}$ & $76.8(18.1)^{\mathrm{b}}$ & $156.8(33.7)^{\mathrm{a}}$ & $188.3(38.5)^{\mathrm{b}}$ \\
\hline Dry weight (g) & $1.22(0.30)^{\mathrm{a}}$ & $1.34(0.33)^{\mathrm{a}}$ & $3.12(0.61)^{\mathrm{a}}$ & $3.89(0.63)^{\mathrm{b}}$ \\
\hline
\end{tabular}

${ }^{a}$ Unprotected plants: -EDU plants for field experiments and NF plants for OTC experiment, respectively; ${ }^{\mathrm{b}}$ protected plants: +EDU plants for field experiments and F plants for OTC experiment, respectively.

\section{Effects on yield parameters}

In table $\mathrm{V}$ the total number of leaves and the dry weight per pot at each harvest are reported. For all treatments, at the final harvest the plants had a higher number of leaves and a higher dry weight than at the first harvest.

In general -EDU and NF plants had fewer leaves than EDU and F plants at both harvests. In particular at the first harvest, the differences between treatments were significant for experiments 2 and 3; the number of leaves decreased by about $15 \%$ in the -EDU and NF plants. At the final harvest the loss of leaves for unprotected plants in comparison to protected ones was 10,12 and $16.7 \%$, respectively, for experiments 1,2 and 3 . The difference was only significant for the experiment performed in the open-top chambers (experiment 3 ).

With regard to leaf dry weight at first harvest, the biomass was not significantly affected and the difference between treatments was less than $10 \%$. At final harvest of experiment 3 the dry weight of NF plants was significantly decreased by $19.8 \%$ compared to $F$ plants. For experiments 1 and 2 the differences were not significant although in -EDU plants the dry weight was less than in EDU plants.

\section{Leaf counting and classification}

Figures 2, 3 and 4 show the results of leaf counting performed at each harvest in experiments 1,2 and 3, respectively. Data are expressed as mean percentages on the total leaves of healthy, senescent and $\mathrm{O}_{3}$ injured leaves per pots. Healthy leaves were always the most numerous in clover plants. The reduction in their percentage in the unprotected plants is always statistically significant. On the contrary the percentage of senescent leaves was higher in the unprotected plants, although the difference between the treatments was significant only for experiment 1 and for the first harvest of experiment 3 .

As described above, $\mathrm{O}_{3}$ injury on clover plants was found in all experiments. The highest percentages of ozone-injured leaves per pot were in plants grown in ambient air without EDU and in those exposed to unfiltered air in OTCs. Very little injury was observed in +EDU and F plants, where symptoms appeared on fewer leaves. For experiment 1 , the percentage of injured leaves was recorded only at the final harvest. At the first harvest we recorded only the number of pots showing visible injury: 12 for -EDU plants and 4 for +EDU plants.

The percentage of damaged leaves for unprotected plants was very similar in experiment 1 at final harvest and in experiments 2 and 3 at first harvest with a mean of about $14 \%$. At final harvest of experiments 2 and 3 the percentages of injured leaves in -EDU and NF plants decreased and were 8.2 and $5.1 \%$, respectively. Comparing field experiment 2 and the OTC experiment the injury categories in +EDU and F plants were similar. In fact for the first harvest the percentages of injured leaves were, respectively, 2.2 and $2.8 \%$, 
Fig 2. Percentage on total leaves of healthy, senescent and ozone-injured leaves per pot at harvest for experiment 1. Different letters on bars of each parameter indicate significant differences between treatments after one-way analysis of variance $(P<0.05)$. ND, not determined.

Fig 3. Percentage on total leaves of healthy, senescent and ozone-injured leaves per pot at harvest for experiment 2. Different letters on bars of each parameter indicate significant differences between treatments after one-way analysis of variance $(P<0.05)$.
Fig 4. Percentage on total leaves of healthy, senescent and ozone-injured leaves per pot at harvest for experiment 3. Different letters on bars of each parameter indicate significant differences between treatments after one-way analysis of variance $(P<0.05)$.
EXPERIMENT 1 (field)

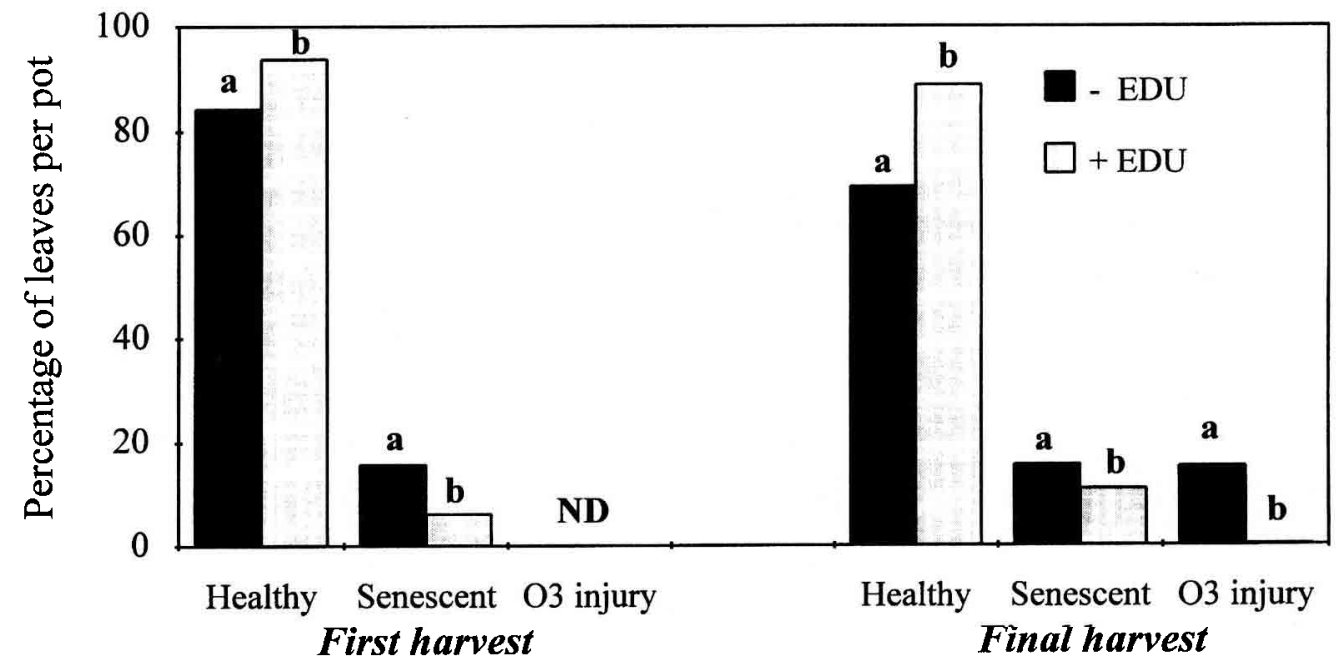

EXPERIMENT 2 (field)

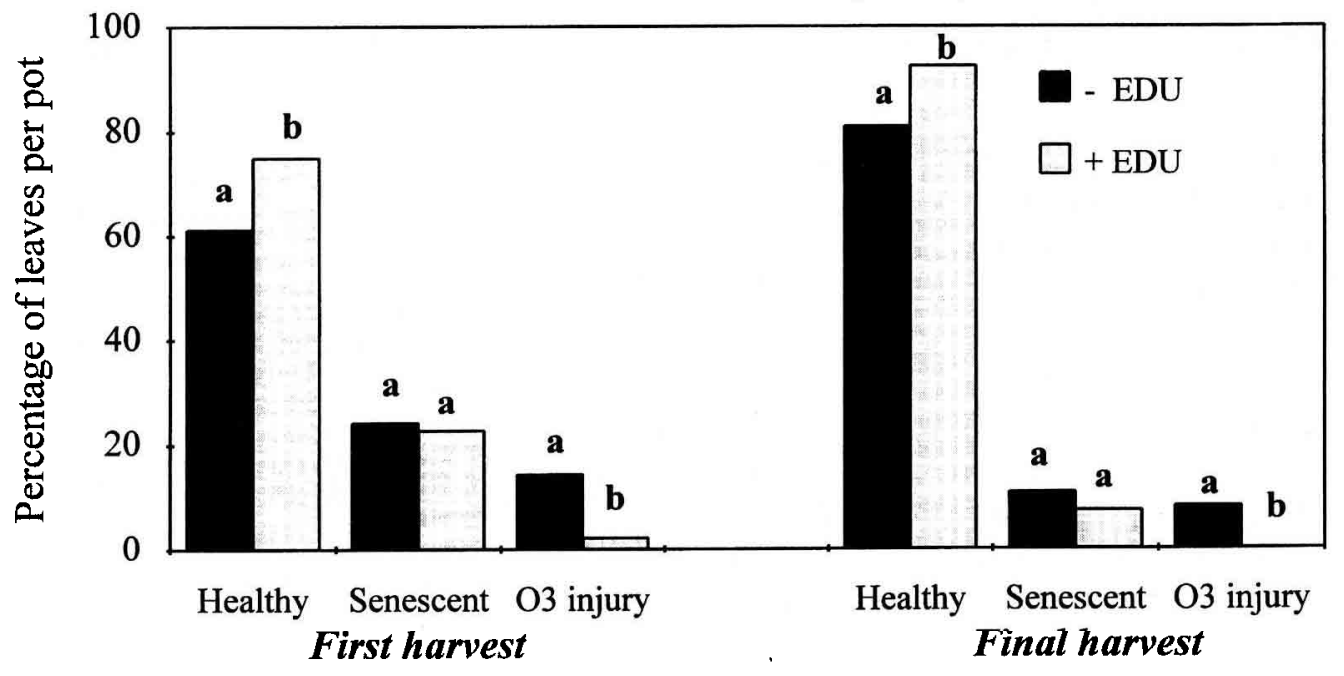

EXPERIMENT 3 (OTCs)

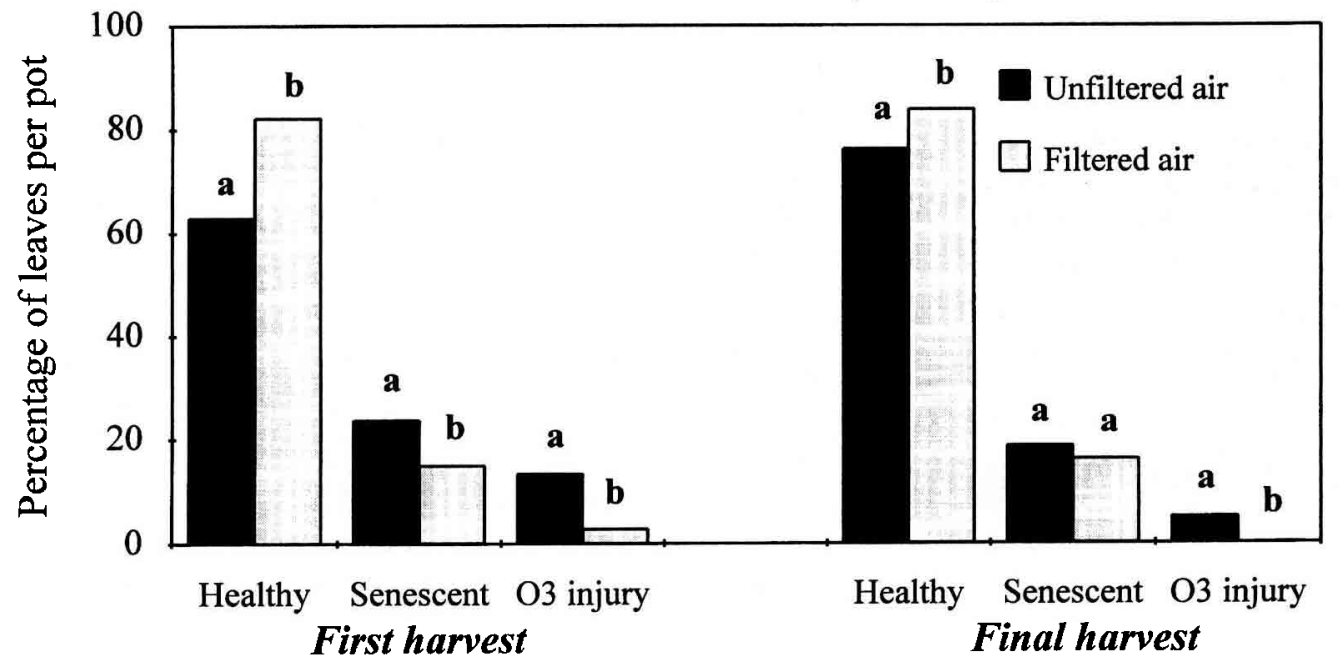


and for the final harvest the percentages were close to zero for both treatments.

\section{DISCUSSION}

Air quality data monitoring show that the concentrations of $\mathrm{SO}_{2}, \mathrm{NO}$ and $\mathrm{NO}_{2}$ in the ambient air were below or close to (in the case of $\mathrm{NO} x$ ) the damage threshold known for sensitive plant species. In particular $\mathrm{SO}_{2}$ concentration recorded was very low, just over the detection limit. Nitrogen oxide concentrations ( $\mathrm{NO}+\mathrm{NO}_{2}$ added in ppb and expressed as $\mathrm{NO}_{2}$ according to UNECE, 1996) were close to the critical level discussed by Caporn (1993) over the growth season $\left(60 \mu \mathrm{g} \mathrm{m}^{-3}\right)$. Literature dealing with $\mathrm{NO} x$ levels close to critical levels indicates growth stimulation as its only adverse effect (Sabaratnum and Gupta, 1988; Sandhu and Gupta, 1989; Taylor and Bell, 1988). It is therefore hypothesised for the present experiment that possible ozoneinduced biomass reduction could not find any synergism with NOx. On the other hand, the ozone data suggest that summertime concentrations of this pollutant, in the area of the Po plain near Milan, can be sufficient to produce visible leaf injury to white clover plants of a sensitive cultivar. Values of the ozone cumulative dose reported here show that our experimental site is characterised by high levels of ozone and may be considered an area at risk from ozone pollution.

Visible injury to clover plants has been reported in many European countries, as reviewed by UN-ECE report (UN-ECE, 1994b; UN-ECE, 1995) and other papers (Becker et al, 1989; Luthy-Krause et al, 1989, Fuhrer et al, 1993).

Therefore, ozone is considered to be the predominant air pollutant in this study. This pollutant reaches the highest values during the vegetative season of a great number of crops. At our experimental site, a great number of $\mathrm{O}_{3}$ episodes over $100 \mathrm{ppb}$ were recorded during the summer months. Under Italian national law (DPR 24.5.88 No 203) the $\mathrm{O}_{3}$ mean hourly concentration of $100 \mathrm{ppb}$ must not be exceeded for more than $1 \mathrm{~h}$ per month. Recently, the critical levels of ozone have been proposed to avoid yield reduction and injury development (UN-ECE, 1996). The provisional short-term critical level of ozone for injury development is defined as an AOT40 of $700 \mathrm{ppb}$ h accumulated over 3 consecutive days. In our experiment, we estimate that this threshold was exceeded over 3-5 days before plants showed ozone visible injury (Fumagalli et al, in prep). This definition of short-term critical level is still under negotiation and requires further studies.

The results of this experiment suggest that not only the injury development but also the severity of ozone injury could be related to the cumulative dose of ozone to which plants have been exposed. For unprotected plants, when the percentage of injured leaves reached about $15 \%$ (experiment 1 at final harvest; experiments 2 and 3 at first harvest), the relative values of AOT40 were quite similar. At the end of experiments 2 and 3 the ozone dose, as well as the injury severity, decreased. Recently Fuhrer et al (1993) have found a qualitative relationship between cumulative $\mathrm{O}_{3}$ parameter (AOT40) and the degree of leaf injury observed in white clover clones.

It has been reported in the literature that sensitive clones of Trifolium spp plants exposed to ozone in controlled conditions show a reduction in dry weight ranging from 19 to $40 \%$ (Horsman et al, 1981; Heagle et al, 1989; Mortensen, 1992). Dry matter reduction in experiments with ambient ozone concentration, has also been reported by several authors (Rebbeck et al, 1988; Heagle et al, 1992; Fuhrer et al, 1994). However, the 1994 data from the coordinated European network (UN-ECE, 1995), show that ozone exposure regimes do not seem to result in a clear reduction in biomass in EDU experiments.

This is also supported by our two EDU experiments. In fact the results show a low and not significant reduction in dry weight in unprotected plants. In particular, the loss was about $10 \%$ in correspondence with high levels of ozone.

In the OTC experiment adverse yield responses are more clear: in the final harvest of experiment 3 differences between filtered and unfiltered air data were in fact quite consistent $(20 \%)$. It must be considered that Italy is an area where the summer ozone concentrations are frequently higher than the Northern European ones and for this reason, an impact of $\mathrm{O}_{3}$ on clover plant biomass could have been expected.

In Italy, in recent years, a reduction in dry weight after ozone exposure under field conditions has been found in beans (Silva et al, 1990; Schenone et al, 1992), in cereals (Schenone and Lorenzini, 1992; Paolacci et al, 1995) and in other crops (Schenone, 1993; Postiglione and Fagnano, 1995).

In the experiment performed with OTCs, a long-term effect of ozone on clover plants seems evident. Bearing in mind that ozone levels during 
the regrowth period were low, the reduction in biomass, related to a reduction in total leaf number, could be due to a prolonged and cumulative action of air pollutant on the plants over the entire period, both before and after the first harvest of the plants. In ozone-sensitive clones, increased response levels to $\mathrm{O}_{3}$ from one growth period to another have also been found (Fuhrer et al, 1994; Heagle et al, 1994), suggesting a carry over effect from previous exposure. Moreover, the higher yield reduction of experiment 3 occurred when a lower, but significant foliar injury occurred. This would suggest that, unlike the suggested cumulative ozone effect on yield, the development of visible injury may be related to a few episodes of high ozone concentration.

Whether or not visible injury is associated with a reduction in plant growth or in biomass needs further investigation. It has been suggested that the extension of foliar injury frequently observed in Northern-Central Europe is rarely sufficient to cause a significant reduction in dry weight (Sanders et al, 1993; Fuhrer, 1994a). At the same time it is known that yield reductions due to ambient levels of ozone also occur in the absence of visible symptoms (Sanders and Benton, 1995).

A threshold for long-term critical level has also been proposed for yield reduction (Fuhrer, 1994a), defined as ozone cumulate dose over 40 ppb needed for at least a $10 \%$ yield reduction; currently this value is $5300 \mathrm{ppb} / \mathrm{h}$ calculated over a 3-month period of plant growth. In our experiments AOT40 has been fully exceeded, although calculated only over a 2 -month period.

The effect of ozone has been evaluated using two different means of protection against this pollutant: EDU application or air filtration in OTCs. EDU treatment significantly reduced the percentage of injured leaves in all experiments, and this level of protection is similar to that obtained by air filtration. EDU appears to have been less effective in limiting the harmful effects of the air pollutant on the plant biomass. The results of experiments 2 and 3, carried out over the same period, are in fact contradictory: plant assimilation of EDU, administered by soil drench, may have been affected by rainfall, sometimes occurring soon after EDU treatment. The effectiveness of EDU in preventing plant injury has been reported for a number of species, such as bean (Whitaker et al, 1990; Miller et al, 1994; Schenone et al, 1995), red clover (Lee et al, 1981) and radish (Kostka-Rick and Manning, 1993; Allegrini et al, 1994). However, the efficiency of EDU in limiting ozone-induced yield losses needs to be investigated in more detail, since relatively little is known about the physiological and biochemical modes of action involved. For red clover leaf disks, for example, EDU retards senescence, probably with the induction of specific free radical scavenging enzymes thus indicating that this chemical protectant may have cytokinin-like activity (Lee et al, 1981). Improved knowledge of the mechanisms involved in the induction of tolerance to ozone in plants by EDU is important for a more precise understanding of their natural resistance to this pollutant (Whitaker et al, 1990). A review of the UN-ECE experimental results, and the possible mechanisms of the protective action of EDU, is reported by Sanders et al (1993).

With regard to the use of OTCs, it has been reported that open-top chambers may modify the inner microclimate and may have either positive or negative effects on plant growth depending on weather conditions and plant maturity (Heagle et al, 1988; Schenone et al, 1992; Fuhrer, 1994b). Furthermore, open-top chambers could affect plant growth response to ozone exposure when compared with field-grown plants. In our experimental design the 'chamber effect' has not been considered because field grown plants were assigned to the EDU experiment. However, the comparison between plants grown inside OTCs, where $\mathrm{O}_{3}$ is the only differing factor, provides important data on plant responses. Despite the restriction of both methods employed, the results obtained by this experiment are complementary and allow a more complete understanding of plant responses to $\mathrm{O}_{3}$.

\section{REFERENCES}

Ainsworth N, Fumagalli I, Giorcelli A, Mignanego L, Schenone G, Vietto L (1996) Assessment of EDU stem injections as a technique to investigate the response of trees to ambient ozone in field conditions. Agric Ecosystems Environ 59, 33-42

Allegrini I, Cortiello M, Manes F, Tripodo P (1994) Physico-chemical and biological monitoring as integrated tools in evaluating tropospheric ozone in urban and semi-rural areas. Sci Total Environ 141, $75-85$

Becker K, Saurer M, Egger A, Fuhrer J (1989) Sensitivity of white clover to ambient ozone in Switzerland. New Phytol 112, 235-243

Caporn SJM (1993) Critical levels for $\mathrm{NO}_{2}$. In: Critical Levels of Air Pollutants for Europe (MR Ashmore, RB Wilson, eds), Egham, UK, 48-54 
Fuhrer J (1994a) The critical level for ozone to protect agricultural crops. An assessment of data from European open-top chamber experiments. In: Critical Levels for Ozone (J Fuhrer, B Achermann, eds), Bern, Switzerland, 42-57

Fuhrer J (1994b) Effects of ozone on managed pasture: I. Effects of open-top chambers on microclimate, ozone flux, and plant growth. Environ Pollut 86, 297-305

Fuhrer J, Perler R, Shariat-Madari H (1993) Growth and gas exchange characteristics of two clones of white clover Trifolium repens $\mathrm{L}$ differing in ozone sensitivity. Angew Bot 67, 163-167

Fuhrer J, Shariat-Madari H, Perler R, Tschannen W, Grup A (1994) Effects of ozone on managed pasture: II. Yield, species composition, canopy structure, and forage quality. Environ Pollut 86, 307-214

Heagle AS (1989) Ozone and crop yield. Ann Rev Phytopathol 27, 397-423

Heagle AS, Body DE, Heck WW (1973) An open-top field chamber to assess the impact of air pollution on plants. J Environ Qual 2, 365-368

Heagle AS, Miller JE, Sherrill DE (1994) A white clover system to estimate effects of tropospheric ozone on plants. J Environ Qual 23, 613-621

Heagle AS, McLaughlin MR, Miller JE, Joyner RL (1992) Response of two white clover clones to peanut stunt virus and ozone. Phytopathology 82 , 254-258

Heagle AS, Rebbeck J, Shafer SR, Blum U, Heck WW (1989) Effects of long-term exposure and soil moisture deficit on growth of a ladino clover-tall fescue pasture. Phytopathology 79, 128-136

Heagle AS, Kress LW, Temple PJ, Kohut RJ, Miller JE, Heggestad HE (1988) Factors influencing doseyield response relationships in open-top field chamber studies. In: Assessment of Crop Loss from Air Pollutants (WW Heck, OC Taylor, DT Tingey, eds), Elsevier Applied Science, London, 141-179

Hill AC, Heggestad HE, Linzon SN (1970) Ozone. In: Recognition of Air Pollution Injury to Vegetation. A Pictorial Atlas (JS Jacobson, AC Hill, eds), Air Pollution Control Association, Pittsburgh, PA, USA

Horsman DC, Nicholls AO, Calder DM (1981) Effects of chronic ozone exposure on the growth of Trifolium subterraneum and Trifolium repens. Aust J Plant Physiol 8, 405-408

Kostka-Rick R, Manning WJ (1993) Dose-response studies with ethylenediurea (EDU) and radish. Environ Pollut 79, 249-260

Lee EH, Bennett JH, Heggestad HE (1981) Retardation of senescence in red clover leaf discs by a new antiozonant, $\mathrm{N}-[2-(2-\mathrm{OxO}-1$-imidazolidinyl)ethyl]-N-phenylurea. Plant Physiol 67, 347350

Luthy-Krause B, Bleuler P, Landolt W (1989) Black poplar and red clover as bioindicators for ozone at a forest site. Angew Bot 63, 111-118
Miller JE, Pursley WA, Heagle AS (1994) Effects of ethylenediurea on snap bean at a range of ozone concentrations. J Environ Qual 23, $1082-1089$

Mortensen LM (1992) Effects of ozone on growth of seven grass and one clover species. Acta Agric Scand 42, 235-239

Paolacci AR, Badiani M, D’Annibale A, Bignami C, Fumagalli I, Fusari A, Lorenzini G, Matteucci G, Mignanego L, Rossini F, Schenone G, Giovannozzi Sermanni G (1995) The effects of realistic ozone exposure on the biology and productivity of peach trees and durum wheat grown in open-top chambers in central Italy. Agr Med Special Volume, 125-139

Pleijel H, Ahlfors A, Skärby L, Pihl G, Selldén G and Sjödin A (1994) Effects of air pollutant emissions from a rural motorway on Petunia and Trifolium. The Sci Total Environ 146/147, 117-123

Postiglione L, Fagnano M (1995) Ozone injury and ethylene diurea: first results on different species in the Campania region. Agr Med Special Volume, 109-118

Rebbeck J, Blum U, Heagle AS (1988) Effects of ozone on the regrowth and energy reserves of a ladino clover-tall fescue pasture. J Appl Ecol 25, 659-681

Sabaratnum S, Gupta G (1988) Effects of $\mathrm{NO}_{2}$ on biochemical and physiological characteristics of soybean. Environ Pollut 55, 149-158

Sanders G, Benton J (1995) Ozone Pollution and Plant Responses in Europe - An Illustrated Guide. ICPCrops Coordination Centre, The Nottingham Trent University, UK

Sanders GE, Booth CE, Weigel HJ (1993) The use of EDU as a protectant against ozone pollution. Proc Symposium on Effects of Air pollution on Agricultural Crops in Europe (HJ Jager, M Unsworth, L De Temmerman, P Mathy, eds) Tervuren, Belgium, 359-369

Sandhu R, Gupta G (1989) Effects of $\mathrm{NO}_{2}$ on growth and yield of black turtle bean (Phaseolus vulgaris L) cv Domino. Environ Pollut 59, 337-344

Schenone G (1993) Air pollution and vegetation in the Mediterranean area. Medit 2, 49-52

Schenone G, Lorenzini G (1992) Effects of regional air pollution on crops in Italy. Agric Ecosystems Environ 38, 51-59

Schenone G, Fumagalli I, Montinaro F, Botteschi G (1989) An open-top chamber system for evaluating the effects of ambient air pollution on crops in Italy. Proc Conference on Man and the Environment. The Plant Components in Anthropic Systems, Rome, Italy, 153-165

Schenone G, Botteschi G, Fumagalli I, Montinaro F (1992) Effects of ambient air pollution in open-top chambers on bean (Phaseolus vulgaris L.). I. Effects on growth and yield. New Phytol 122 , 689-697

Schenone G, Fumagalli I, Mignanego L, Violini G (1995) Effects of ambient ozone on bean 
(Phaseolus vulgaris L): results of an experiment with the antioxidant EDU in the Po plain (Italy) in the 1993 season. Agric Med Special Volume, 104108

Silva S, Scotti I, Botteschi G, Fumagalli I (1990) Effetti di inquinanti atmosferici sui parametri produttivi di fagiolo coltivato in open-top chambers. Proc Conference on Inquinamento atmosferico: controllo e difesa della qualità dell'aria, Milano, Italy, 564-576

Taylor HJ, Bell JNB (1988) Studies on the tolerance to $\mathrm{SO}_{2}$ of grass populations in polluted areas. $\mathrm{V}$ Investigations into the development of tolerance to $\mathrm{SO}_{2}$ and $\mathrm{NO}_{2}$ in combination and $\mathrm{NO}_{2}$ alone. New Phytol 110, 327-338

UN-ECE (1994a) International Cooperative Programme to Investigate the Effects of Air Pollutants and Other Stresses on Agricultural
Crops and Semi-Natural Vegetation. Experimental protocol for 1994. ICP-Crops Coordination Centre, The Nottingham Trent University, UK

UN-ECE (1994b) Progress Report for the ICP-Crops. ICP-Crops Coordination Centre, The Nottingham Trent University, UK

UN-ECE (1995) Progress Report for the ICP-Crops. ICP-Crops Coordination Centre, The Nottingham Trent University, UK

UN-ECE (1996) Effects of Nitrogen and Ozone. Report prepared by the International Cooperative Programmes and the Mapping Programme under the Working Group on Effects, Oslo, Norway

Whitaker BD, Lee EH, Rowland RA, (1990) EDU and ozone protection: foliar glycerolipids and steryl lipids in snapbean exposed to ozone. Physiol Plant $80,286-293$ 